\title{
Eğitimin İşlevlerinin Gerçekleşme Düzeyinin Öğretmen Algılarına Göre İncelenmesi
}

\section{Serkan Ünsal ${ }^{1}$}

Abdullah Gökdaş²

\section{Öz}

\section{Type/Tür:}

Research/Araştırma

Received/Geliş Tarihi:

January 16/ 16 Ocak 2020

Accepted/Kabul Tarihi:

November 12/ 12 Kasim

2020

Page numbers/Sayfa No: 1133-1157

Corresponding

Author/İletişimden

Sorumlu Yazar: serkanunsal09@hotmail.com

\section{$\checkmark$ iThenticate}

This paper was checked for plagiarism using iThenticate during the preview process and before publication. / $\mathrm{Bu}$ çalışma ön inceleme sürecinde ve yayımlanmadan önce iThenticate yazılımı ile taranmiştır.

Copyright@ 2017 by Cumhuriyet University, Faculty of Education. All rights reserved.
$\mathrm{Bu}$ araştırmanın amacı, eğitimin işlevlerinin gerçekleşme düzeylerini öğretmen algiları doğrultusunda incelemektir. Araştırma nicel yaklaşımla desenlenmiş ve araştırmada tarama modeli kullanılmıştır. Araştırmanın evrenini 2018-2019 eğitim öğretim yılında Kahramanmaraş ilinde görev yapan öğretmenler oluştururken, örneklemini ise aynı ilin Dulkadiroğlu ve Onikişubat merkez ilçelerinde görev yapan 418 gönüllü öğretmen oluşturmuştur. Araştırmada veri toplama aracı olarak araştırmacılar tarafından geliştirilen "Öğretmenlerin Eğitimin İşlevlerinin Gerçekleşme Düzeyine İlişkin Algılarını Belirleme Ölçeği " kullanılmıştır. Yapılan analizler ölçeğin öğretmenlerin eğitimin işlevlerini gerçekleştirme düzeyine ilişkin algılarını belirleme de kullanılabilecek nitelikte geçerli ve güvenilir bir ölçme aracı olduğunu ortaya koymuştur. Ölçek; bireysel işlev, siyasal işlev, toplumsal işlev, ekonomik işlev olmak üzere dört faktörlüdür. Öğretmenlerin algılarının cinsiyet ve okul türü değişkenine göre farklılık gösterip göstermediğini belirlemek için bağımsız gruplar t testi uygulanmıştır. Mesleki kıdem, görev yapilan okul kademesi ve mezun olunan okul türü değişkenlerine göre farklılık gösterip göstermediğini belirlemek için Tek Yönlü Varyans Analizi (ANOVA) yapılmıştır. Gruplar arası farklılı̆̆ı belirlemek için ise LSD testi yapılmıştır. Araştırmanın sonucunda, öğretmenlerin eğitimin bireysel işlevlerinin gerçekleşme düzeyine yönelik algılarının katılıyorum düzeyinde, toplumsal, siyasal ve ekonomik işlevlerinin gerçekleşme düzeylerine yönelik algılarının ise kararsızım düzeyinde olduğu belirlenmiştir. Bunun yanında eğitimin işlevlerinin gerçekleşme düzeylerine ilişkin alg1 düzeyleri cinsiyet, okul türü, çalışılan okul kademesi ve kıdem değişkenleri açısından anlamlı bir şekilde farklılaşırken, mezun olunan okul türü değişkeni açısından anlamlı bir şekilde farklılaşmamıştır.

Anahtar Kelimeler: Eğitim, bireysel işlev, toplumsal işlev, ekonomik işlev, siyasal işlev

\section{Suggested APA Citation/Önerilen APAtıf Biçimi:}

Ünsal, S. \& Gökdaş, A. (2020). Eğitimin işlevlerinin gerçekleşme düzeyinin öğretmen algılarına göre incelenmesi. Cumhuriyet International Journal of Education, 9(4), 1133-1157. http:/ / dx.doi.org/10.30703/cije.675779

\footnotetext{
* Bu çalışma ikinci yazarın yüksek lisans tezinden üretilmiştir

11Doç. Dr. KSÜ. Eğitim Bilimleri Bölümü, Kahramanmaraş/Türkiye

Assoc. Prof. Dr. Kahramanmaraş Sütçü İmam University, Department of Educational Sciences, Kahramanmaraş/Turkey e-mail: serkan-unsal09@hotmail.com ORCID ID: orcid.org/0000-0003-0367-0723
} 


\title{
Examination of Teachers' Perceptions Towards the Realization Level of the Educational Functions
}

\begin{abstract}
This study aims to examine the teachers' perceptions regarding the level of realization of the functions of education. The research was designed with a quantitative approach and a survey model was used. The teachers working in Kahramanmaraş in the 2018-2019 academic year were the population of the research, the sample was composed of 418 volunteer teachers working in the central districts, Dulkadiroğlu and Onikişubat. As a data collection tool, the scale developed by the researchers was used to determine the teachers' perceptions towards the realization level of the functions of education. Statistical analysis revealed that the scale is a valid and reliable measurement tool that can be used to determine the teachers' perceptions of the realization level of the functions of education. The scale consists of four factors: individual function, political function, social function and economic function. Independent groups t-test was applied to detect whether teachers' perceptions differ according to gender and type of school. One-way analysis of variance (ANOVA) was performed to ascertain whether there is a significant difference between the variables of seniority, school level and the type of school graduated. LSD test was utilized to decide on the difference between the groups. This research concludes that the perceptions of teachers about the realization level of the individual functions of education are at the level of 'agree' and the perceptions of realization level in terms of social, political and economic functions of edcation are 'undecided'. In addition, while the perception levels regarding the realization levels of the functions of education differ significantly depending on the gender, school type, school level and seniority variables, it does not differ significantly in terms of the type of school graduated.
\end{abstract}

Keywords: Education, individual function, social function, economic function, political function

\section{Giriş}

Geçmişten günümüze ekonomik, toplumsal, sosyal ve kültürel anlamda toplumların değişiminde önemli faktör olan eğitim (Bal ve Artut, 2013; Çetin ve Aydın, 2019; Chakraborty, Chakraborty, Singh Dahiya ve Timajo, 2018; Khan, Fauzee ve Daud, 2014; Takala, 2010) insanlık tarihi kadar eski bir olgudur/kurumdur (Hoşgörür ve Taştan, 2012 ). Eski ve evrensel bir kurum olan eğitim; birey, toplum ve devletin beklentileri doğrultusunda değişerek/gelişerek varlığını devam ettirmektedir (Avcı, 2012). İlkel toplumdan modern topluma kadar değişik formlarda rastlanılan eğitim olgusu farklı açılardan tanımlanmaya çalışılmıştır. Sosyolojik açıdan eğitim bireyin, toplumun kültürel değerlerini içselleştirerek toplumsal hayata hazırlanması olarak tanımlanırken (Eskicumalı, 2002) pedagojik açıdan eğitim bireyin davranışında, kendi yaşantısı yoluyla ve kasıtlı (amaçlı ve planlı) olarak istendik davranış değişikliği meydana getirme süreci (Ertürk, 1997, s. 12) olarak tanımlanmıştır. Bununla birlikte eğitime yönelik farklı tanımlar olsa da birey, toplum ve devlet açısından eğitimin birçok amaca ve işleve sahip olduğu söylenebilir. Bu amaçlar, zamana ve toplumsal koşullara bağlı olarak değişebilmektedir. Eğitimin amacı, geleneksel toplumda bireyin uyumunu sağlama iken modern toplumda ekonominin ihtiyaç duyduğu beceri ve nitelikleri bireye kazandırmaktır (Ballantine, Hammack ve Stuber, 2017). Weber, eğitimin toplumlara ve zamana bağlı olarak amacının değiştiğini belirtse de bireye belirli nitelikler kazandırmak ve belli alanlarda uzmanlık eğitimi vermek şeklindeki iki amacının değişmediğini belirtmektedir (Aydın, 1997). 
Eğitimin genel olarak amacını Çakmak (2008) bireysel ve evrensel değerlere sahip çıkan, bilgiyle donanmış, sağlıklı bir toplum yapısı meydana getirmek olarak belirtirken, Hoşgörür ve Taştan (2012) ise bireyin toplumsal amaçlar çerçevesinde yetiştirilerek insan kaynağından verimli şekilde faydalanmak olduğunu belirtmiştir. Eğitimin bahsedilen bu amaçlarına göre işlevlerini gerçekleştirdiği söylenebilir. Bu açıdan eğitim sistemi organize ya da reorganize edilirken başlangıç noktası, önce amaç, sonra işlev olmaktadır (Tezcan, 2016).

Eğitimin işlevlerini yerine getiriş şekli, hangi işlevlerinin öncelik oluşturduğu ve bu işlevlerini gerçekleştirmesinde beklenen amaçların neler olduğu konularında toplumlar arasında farklılık bulunmaktadır (Fidan ve Erden, 1998). Başka bir ifade ile bazı toplumlar için eğitimin siyasal işlevleri öncelik oluştururken, bazı toplumlar için ise eğitimin toplumsal işlevleri diğer işlevlere göre daha öncelik oluşturmaktadır. İEğitimin işlevlerinin hangilerinin öncelikli olduğunu belirleyen faktörler; ülkelerin gelişmişlik düzeyi, toplumun eğitimden beklentileri ve eğime yükledikleri anlamdır (Ünsal, Bağçeci, Meşe ve Korkmaz, 2016). Eğitimin işlevleri açık ve gizli işlevler olmak üzere iki kategori altında toplanmaktadır. Eğitimin açı işlevleri, milli eğitimin amaçları çerçevesinde oluşturulan öğretim programları aracılığıyla eğitimin tüm kademelerinde uygulanırken (Doğan, 2014), gizli işlevler ise amaçlanmayan ve bilinmeyenler şeklinde belirtilmektedir (Akın, Şimşek ve Erdem, 2007). Temelde eğitimin açık ve gizli işlevlerini birbirinden ayırmak oldukça güç olmasına rağmen gizli işlevlerin oldukça çok ve çeşitli olduğu ifade edilmektedir (Akın, Şimşek ve Erdem, 2007).

Genel anlamda eğitimin açık işlevleri; bireysel, toplumsal, ekonomik, siyasal olmak üzere dört başlık altında ele alınmaktadır. Eğitimin toplumsal işlevinin başında öğrencilerin toplumun bir üyesi haline getirme süreci olan sosyalleştirme gelmektedir (Barkan, 2013). Eğitim, bireylerin içinde yaşadıkları topluma uyum sağlamalarını ve o topluma ait rol kalıplarını öğrenmelerini sağlayarak sosyalleşmesine yardımcı olur (Erden, 1998). Başka bir ifade ile doğduğu anda biyolojik bir varlık olan insanoğlu, zamanla üyesi olduğu toplumun inancını, değer yargılarını, davranış kalıplarını, ilişki biçimini eğitim yoluyla öğrenerek sosyal bir varlık hâline gelir (Ünsal ve Korkmaz, 2018). Eğitim kurumları sosyalleşme süreci ile kültürü bireylere aktarır ve böylece kültürel mirasın sürekliliğini sağlar (Tezcan, 2016). Eğitim, okullarda yetiştirmiş olduğu, bilim adamları, sanatçılar, şair ve yazarların çalışmalarıyla kültürün yenilenmesine ve zenginleşmesine de katkı sağlamaktadır (Barkan, 2013). Eğitim kurumunun diğer önemli bir işlevi toplumsal hareketliliği gerçekleştirmektir (Topses, 2016). Özellikle açık toplum yapısının egemen olduğu modern toplumlarda eğitim kurumu dikey hareketliliğin gerçekleşmesini mümkün kılarak alt tabakada yer alan bireylerin daha üst tabakalara geçmesini sağlamaktadır (Ünsal ve Korkmaz, 2018).

Eğitimin açık işlevlerinden biride ekonomik işlevdir. Bir ülkenin ekonomik açıdan güçlenmesi ve kalkınması için ihtiyaç duyulan nitelikli bireylerin yetiştirilmesi eğitimin ekonomik işlevleri arasında yer alır (Yıldız, 2006). Eğitim kurumları talep edilen insan gücünü yetiştirmenin yanında bireylere tüketici davranışlarını kazandırma yoluyla ülkenin ekonomik gelişmesine katkıda bulunur (Fidan ve Erden,1998). Herhangi bir mesleği olmayanlara mesleki bilgi ve beceriler sunmak, mesleği olanlara da yeni bilgi ve beceriler kazandırmak eğitimin diğer ekonomik işlevleri arasında yer almaktadır (Yıldız, 2006). 
Eğitimin siyasal işlevlerinin başında toplumun mevcut varlığını ve gelecekteki bütünlüğünü korumak gelmektedir. Koruma eylemini sinifsal, bölgesel, siyasi bölücülük, ayrımcılık ve kutuplaşma anlayışlarının oluşmasını engelleyerek yaparken gelecekteki bütünlüğü sağlamak için ise bireylere siyasal bilinç kazandırmaktadır (Yıld1z, 2006). Eğitim kurumları, topluma milli bilinç kazandırma yoluyla siyasal sisteminde devam etmesini sağlamaktadır (Fidan ve Erden, 1998). Eğitimin başka bir siyasal işlevide, liderlerin seçilmesi ve eğitilmesidir (Tezcan, 2016).

Bireysel açıdan eğitimin işlevi öğrencilerin kendi yeteneklerini keşfedip geliştirmesine, akademik ve akademik olmayan alanlarda bir takım bilgi ve beceriler kazanmasına yardımcı olmaktır (Şişman, 2007). Ayrıca bireylerin yaratıcılıklarının gelişimine katkı sunmak, onları hayata hazırlamak, kendiyle barışık bir hayat sürmelerini sağlamakda eğitimin diğer bireysel işlevleridir (Hoşgörür ve Taştan, 2012).

Öğretmenlerin eğitim sisteminin ana öğelerinden biri kabul edilmesi (Ada ve Akan, 2007; Adıgüzel, 2008) toplumsal yaşamı ve eğitimin niteliğini etkileyen önemli bir faktör olması (Çetin ve Doğan, 2018; Snoek, Swennen ve van der Klink 2011; 2011; Ünsal, A ğcam ve Korkmaz, 2017) öğrenme ve öğretme ortamını düzenlemesindeki öneminden (Başarır, Sarı ve Çetin, 2014) dolayı eğitimin işlevlerininde gerçekleşmesinde öğretmenlere büyük sorumluluklar düştüğü söylenebilir. Bu açıdan öğretmenlerin eğitimin işlevlerini yerine getirmesiyle ilgili algı ve düşünceleri bu çalışmada konu edinilmiştir.

Ülkelerin ilerlemesi ve gelişmesi, toplumun sağlıklı bir şekilde varlığını devam ettirmesi, bireyin kendini gerçekleştirerek mutlu bir hayat sürmesi eğitimin kendisinden beklenen açık ve gizli işlevlerini yerine getirmesi ile mümkün olabileceği söylenebilir. Bu durumda tartışılması gereken konu eğitimin işlevlerinin yerine getirip getirmediğidir. Alanyazın incelendiğinde bu soruya cevap teşkil edecek bir araştırmaya rastlanmamış olması araştırmacılar tarafından bir eksiklik olarak değerlendirilmiştir. Bu doğrultuda araştırmanın problem cümlesi "Öğretmenlerin algılarına göre eğitimin işlevlerinin gerçekleşme düzeyi nedir?" şeklinde oluşturulmuştur.

Bu kapsamda aşağıdaki sorulara cevap aranmıştır.

1. Öğretmenlerin algılarına göre eğitimin bireysel işlevlerinin gerçekleşme düzeyi nedir? ?

2. Öğretmenlerin algılarına göre eğitimin toplumsal işlevlerinin gerçekleşme düzeyi nedir?

3. Öğretmenlerin algılarına göre eğitimin ekonomik işlevlerinin gerçekleşme düzeyi nedir?

4. Öğretmenlerin algılarına göre eğitimin siyasal işlevlerinin gerçekleşme düzeyi nedir?

5. Öğretmenlerin eğitimin işlevlerini yerine getirmedeki alg1 düzeyleri; cinsiyetlerine, çalıştığı okul türüne, çalıştığ1 okul kademesine, mezun olunan okul türüne göre anlamlı biçimde farklılaşmakta mıdır?

\section{Yöntem}

Bu bölümde araştırmanın modeli, evren ve örneklemi, veri toplama araçları ve verilerin analizine ilişkin bilgiler sunulmaktadir. 


\section{Araştırmanın Modeli}

$\mathrm{Bu}$ araştırmada öğretmenlerin eğitimin işlevlerini gerçekleştirme konusundaki algılarının ne düzeyde olduğunun belirlenmesi amaçlandığından nicel araştırma modellerinden betimsel tarama modeli kullanılmıştır. "Tarama modelleri, geçmişte ya da halen var olan bir durumu var olduğu şekliyle betimlemeyi amaçlayan araştırmalardır" (Karasar, 2005; 183).

\section{Araştırmanın Evren ve Örneklemi}

Araştırmanın evreni, 2018-2019 eğitim-öğretim yılında Kahramanmaraş il merkezinde Millî Eğitim Bakanlığına bağlı okullarda görev yapan öğretmenlerden oluşmaktadır. Araştırmanın örneklemini ise aynı ilin Onikişubat ve Dulkadiroğlu merkez ilçelerindeki ilkokul, ortaokul ve liselerde görev yapan 418 öğretmen oluşturmaktadır. Çalışmanın örneklemine ilişkin demografik bilgiler Tablo 1'de verilmiştir.

Tablo 1.

A raştırmaya Katılan Öğretmenlere İlişkin Demografik Bilgiler

\begin{tabular}{llcc}
\hline & Değişkenler & $\mathrm{N}$ & $\%$ \\
\hline \multirow{3}{*}{ Cinsiyet } & Kadın & 146 & 34,9 \\
& Erkek & 272 & 65,1 \\
& Toplam & 418 & 100 \\
\hline \multirow{3}{*}{ Okul Türü } & Özel & 78 & 18,7 \\
& Devlet & 340 & 81,3 \\
& Toplam & 418 & 100 \\
\hline \multirow{5}{*}{ Okul Kademesi } & Ilkokul & 142 & 34 \\
& Ortaokul & 140 & 33,5 \\
& Lise & 136 & 32,5 \\
& Toplam & 418 & 100 \\
\hline \multirow{5}{*}{ Mesleki Kidem } & $0-5$ yil & 54 & 12,9 \\
& $6-11$ yil & 77 & 18,4 \\
& $12-17$ yil & 92 & 22,0 \\
& $18-22$ yil & 107 & 25,6 \\
& 23 yil ve üzeri & 88 & 21,1 \\
& Toplam & 418 & 100 \\
\hline \multirow{5}{*}{ Mezun Olunan Okul Türü } & Lisans & 285 & 68,2 \\
& Lisansüstü & 82 & 19,6 \\
& Toplam & 51 & 12,2 \\
& & 418 & 100 \\
\hline
\end{tabular}

Tablo 1 incelendiğinde cinsiyet değişkeni göre öğretmenlerin 146's1 (\%34,9) kadın, 272 'si $(\% 65,1)$ erkek olduğu, okul türü değişkenine göre öğretmenlerin $78^{\prime}$ inin $(\% 18,7)$ özel okulda, 340'ının (\%81,3) devlet okulunda çalıştığı anlaşılmaktadır. Okul kademesi değişkeni göre katılımcıların 142'si (\%34) ilkokul öğretmeni 140'1 (\%33,5) ortaokul öğretmeni ve 136's1 (\%32,5) ise lise öğretmenidir. Mesleki kıdem değişkenine göre öğretmenlerin 54'ü (\%12,9) 0-5 yıllık, 77'si (\%18,4) 6-11 yıllık, 92'si (\%22,0) 12-17 yıllık, 107 'si $(\% 25,6)$ 18-22 yıllık ve 88'i de $(\% 21,1) 23$ yıl ve üzeri kıdeme sahiptir. 


\section{Veri Toplama Aracı Geliştirme Süreci}

Araştırmada veri toplama aracının geliştirme sürecine yönelik işlemler, geçerlilik ve güvenirlik çalışmaları sırasıyla aşağıda açıklanmıştır.

\section{İşlem}

Öğretmenlerin eğitimin işlevlerini yerine getirmeye ilişkin alg1 düzeylerini belirleme ölçeğinin geliştirme sürecinde ilk olarak alanda var olan Ünsal vd., (2015) tarafından geliştirilen eğitimin işlevlerini değerlendirme ölçeği incelenmiştir. Bu ölçek üzerinde değişiklikler yapılmıştır. Ölçeğin orjinali üçlü likert tipinde iken yeni geliştirilen ölçek (1) Kesinlikle katılmıyorum, (2) Katılmiyorum, (3) Kararsızım, (4) Katıliyorum ve (5) Kesinlikle Katılıyorum şeklinde beşli Likert türüne dönüştürülmüştür. Sonraki aşamada ise ölçeğin ismi “Öğretmenlerin Eğitimin İşlevlerinin Gerçekleşme Düzeyine İlişkin Algılarını Belirleme Ölçeği" (ÖEİGDİABÖ) şeklinde değiştirilmiştir. Daha sonraki süreçte ölçeğin orjinal halinde bulunan soru maddelerine yeni sorular eklenerek 40 maddelik bir madde havuzu oluşturulmuştur. Uzman görüşü için eğitim programları ve öğretimi ile ölçme değerlendirme alanındaki iki akademisyene başvurulmuştur. Uzman görüşleri doğrultusunda 40 maddelik madde havuzu 37 maddeye indirilmiştir. Son aşamada, anlatım, noktalama ve imla açısından inceleme yapan Türkçe öğretmenin görüşleri doğrultusunda ölçekten iki madde çıkartılmıştır. İki madde çıkartıldıktan sonra ölçek geliştirme süreci 35 madde üzerinden gerçekleşmiştir.

\section{Geçerlik Çalışmaları}

Ölçüt bağlantılı geçerlik, yapı bağlantılı geçerlik, kapsam bağlantılı geçerlik, ve görünüş geçerliği bir ölçme aracının geçerliliği belirlemek için kullanılmaktadır (Büyüköztürk, 2006). Bu ölçme aracının geçerliliğini belirlemede yapı geçerliği kullanılmıştır.

\section{Yapı Geçerliği}

"Yapı geçerliği test sonucunda elde edilen puanların testlerle ölçülmek istenen kavramın (yapının) gerçekte ölçülebildiği derece ile ilgilidir" (Büyüköztürk, 2008, s. 169). Ölçeğin yapı geçerliğinin incelenmesi amacıyla açımlayıcı ve doğrulayıcı faktör analizine başvurulmuş ve Varimax Döndürme (Rotation) metodu kullanılmıştır.

\section{Açımlayıcı Faktör Analizi}

"Faktör analizi birbiriyle ilişkisi bulunan çok sayıdaki değişkenin az sayıda anlamlı ve birbirinden bağımsız faktörler haline getirilmesi için kullanılır" (Kalayc1, Albayrak, Eroğlu, Küçüksille, Ak, Karaltı ve Antalyalı 2005; 321). ÖEIYABÖ’ nin yapı geçerliğinin incelenmesi amacıyla ilk aşamada açımlayıcı faktör analizi yapılmıştır. Faktör analizinden önce verilerin faktör analizine uygunluğunun tespit edilmesi amacıyla Kaiser Meyer Olkin (KMO) katsayısı ve Bartlett's Sphericity testi hesaplanmıştır.

Yapılan KMO testinde bulunan, 0.96, değeri örneklem büyüklüğünün yeterli olduğunu göstermektedir. Bartlett's Sphericity testi 0,00 düzeyinde anlamlı çıkmıştır $(p<0.05)$. Elde edilen bu verilerin ölçeğin faktör analizi yapmak için yeterli olduğuna karar verilmiş ve temel bileşenler analizi yapılmıştır.

Yapılan analiz neticesinde ortaya çıan faktör yükleri Tablo 2 'de verilmiştir. 
Tablo 2.

ÖEIYYABÖ Madde Faktör Yük Değerleri

\begin{tabular}{ccccc}
\hline 1.Boyut & $\begin{array}{c}\text { 2.Boyut } \\
\text { (Toplumsal) }\end{array}$ & $\begin{array}{c}\text { 3.Boyut } \\
\text { (Bireysel) }\end{array}$ & $\begin{array}{c}\text { Boyut } \\
\text { (Siyasal) }\end{array}$ \\
\hline V37 & 0.78 & & & \\
V40 & 0.77 & & & \\
V39 & 0.73 & & & \\
V36 & 0.73 & & & \\
V38 & 0.67 & & & \\
V22 & 0.64 & & & \\
V20 & 0.62 & & & \\
V33 & 0.61 & & & \\
V34 & 0.57 & 0.79 & & \\
V12 & 0.55 & 0.78 & & \\
V15 & 0.51 & 0.73 & & \\
V28 & & 0.69 & & \\
V27 & & 0.57 & & \\
V30 & & 0.54 & & 0.75 \\
V29 & & & 0.85 & \\
V26 & & & & 0.56 \\
V32 & & & & \\
V2 & & & & \\
V1 & & & & \\
V3 & & & & \\
V8 & & & & \\
V18 & & & & \\
V19 & & & & \\
V17 & & & & \\
V16 & & & & \\
\hline
\end{tabular}

Yapılan temel bileşenler analizi neticesinde, elde edilen döndürülmüsş (varimax ) faktör yükleri matrisine göre birinci faktör altında 11 madde (V12, V15, V20, V22, V33, V34, V36, V37, V38, V39, V40), ikinci faktör altında altı madde (V26, V27, V28, V29, V30, V32), üçüncü faktör altında dört (V1, V2, V3, V8), dördüncü faktör altında ise dörtmadde (V16, V17, V18, V19) yer almaktadır. "Bir madde hangi faktör altında mutlak değer olarak, büyük ağırlığa sahipse, o değişken o faktörle yakın ilişki içerisindedir" (Kalaycı vd., 2005, s. 330). Faktör ağırlıklarının oranın ne olduğu konusunda uzlaşılmış bir kriter olmamakla beraber bu çalışmada kriter, 0,50 olarak benimsenmiştir. Literatür doğrultusunda faktörlerin adlandırılması; birinci faktör toplumsal işlev, ikinci faktör ekonomik işlev, üçüncü faktör bireysel işlev, dördüncü faktör ise siyasal işlev şeklinde isimlendirilmiştir.

\section{Doğrulayıcı Faktör Analizi}

ÖEİGDİABÖ'nin yapı geçerliği için ölçekteki faktörlerin doğrulanması amacıyla doğrulayıcı faktör analizi (DFA) uygulanmıştır. DFA ile ilgili hesaplamalar için Mplus programından yararlanılmıştır. Mplus programı ile oluşturulan Path diyagramı ve DFA sonuçları Şekil 1ve Tablo 3' te verilmiştir. 


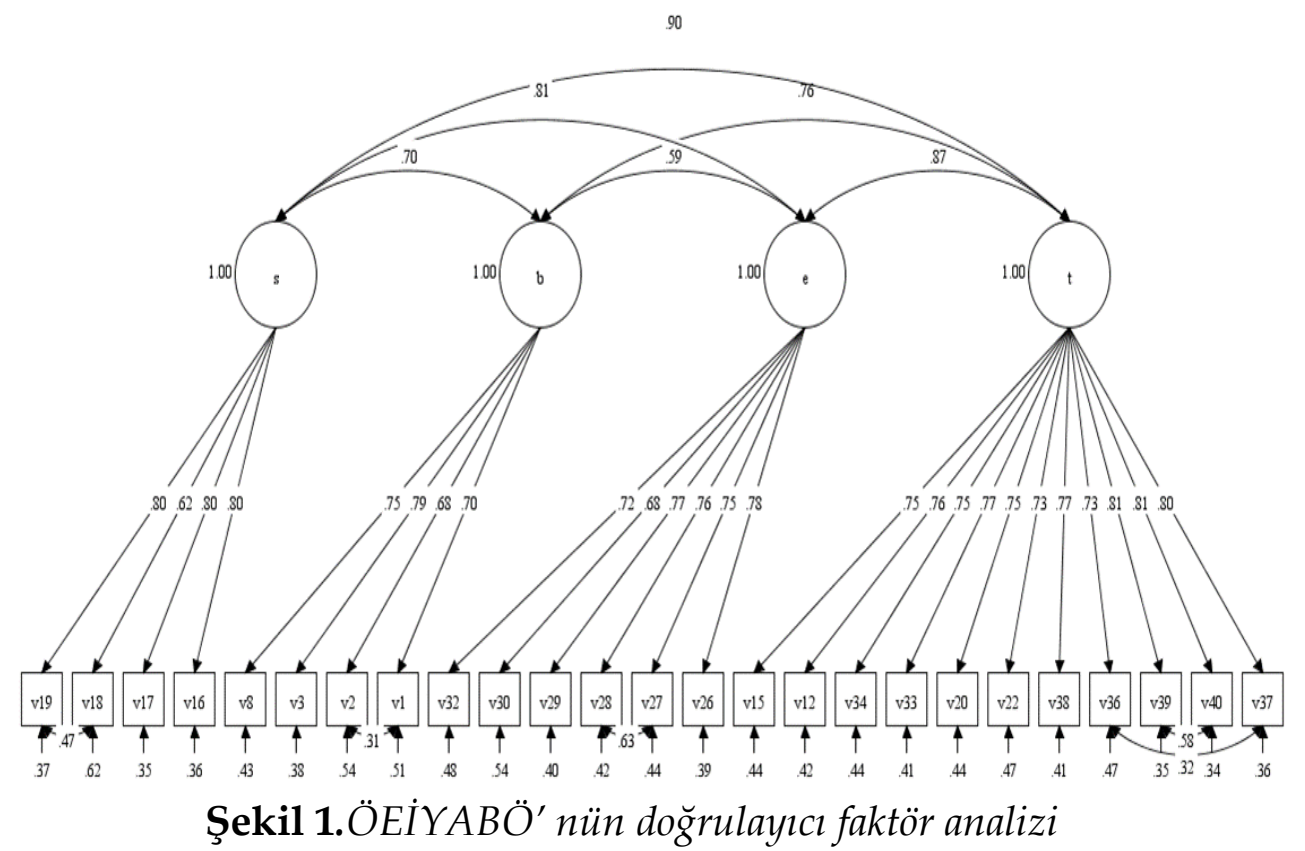

DFA'dan elde edilen modele ait uyum indekslerinden ilki ki-kare istatistiği $\left(\mathrm{X}^{2}\right)^{\prime}$ dir. Ancak tek başına değerlendirilen bir istatistik değildir. Bu nedenle serbestlik derecesi (sd) ile oranlanarak değerlendirmeye alınır. $X^{2} / \mathrm{sd}$ oranı $3^{\prime}$ ten küçük ise, uyum mükemmel; 5 ' in altında ise uyum kabul edilebilir düzeydedir. Buna göre, yapılan analiz için X²/sd oranının $(839,237$ / $264=3,38)$ kabul edilebilir düzeyde uyum değeri verdiği ifade edilebilir (Sümer, 2000).

Tablo 3.

Doğrulayıcı Faktör Analizine İlişkin ÖEİGDİABÖ'nün Uyum İndeksleri

\begin{tabular}{llll}
\hline $\begin{array}{l}\text { İncelenen Uyum } \\
\text { İndeksleri }\end{array}$ & Mükemmel Uyum & Kabul Edilebilir Değerleri & $\begin{array}{l}\text { Ölçeğin Uyum } \\
\text { Değerleri }\end{array}$ \\
\hline CFI & $0.95 \leq$ CFI $\leq 1.00$ & $0.90 \leq$ CFI $\leq 0.95$ & 0.923 \\
NNFI(TLI) & $0.95 \leq$ NNFI(TLI) $\leq 1.00$ & $0.90 \leq$ NNFI(TLI) $\leq 0.95$ & 0.912 \\
RMSEA & $0.00 \leq$ RMSEA $\leq 0.05$ & $0.05 \leq$ RMSEA $\leq 0.08$ & 0.073 \\
\hline
\end{tabular}

Tablo 3 incelendiğinde ÖEIYABÖ RMSEA değerinin .073, NNFI değerinin 0.912 ve CFI değerinin 0.923 olduğu görülmektedir. ÖEIYYABÖ’ i için elde edilen bu değerlerin kabul edilebilir düzeyde bir uyum indeksi olduğu söylenebilir (Sümer, 2000: Yılmaz ve Çelik, 2009). Bu bulgulara dayanarak ölçeğin yap1 geçerliğinin sağlandığı ifade edilebilir.

\section{Güvenirlik}

Ölçeğin güvenirliğini hesaplamak için, Cronbach'Alpha iç tutarllık katsayısı hesaplanmıştır. Cronbach'Alpha iç tutarlılık katsayısı aynı faktör altındaki soruların toplamdaki güvenirlik seviyesini göstermektedir. İç tutarlılık katsayısı 0.70 ve üstü olduğu durumlarda ölçeğin yeterli güvenirlikte olduğu kabul edilebilir (Sipahi, 
Yurtkoru ve Çinko, 2006, s. 89). ÖEİGDİABÖ’ nin alt boyutlarına ilişkin iç tutarlılık katsayıları Tablo 4 'te verilmiştir.

Tablo 4.

ÖEİYABÖ'nün İç Tutarlık Güvenirlik Katsayısı

\begin{tabular}{llc}
\hline & İç Tutarlık & Madde Sayısı \\
\hline Testin Bütünü & .961 & 25 \\
Toplumsal & .944 & 11 \\
Ekonomik & .896 & 6 \\
Bireysel & .839 & 4 \\
Siyasal & .865 & 4 \\
\hline
\end{tabular}

Ölçeğin güvenirliğini belirlemek için hesaplanan iç tutarlılık katsayısı toplumsal işlev için .944, ekonomik işlev için .896, bireysel işlev için .839, siyasal işlev .865, ölçeğin tamamı için ise .961 bulunmuştur. Bu bulgular eğitimin işlevlerini değerlendirme ölçeğinden elde edilen puanların güvenirliliğinin yüksek olduğunu göstermektedir. Ölçekte yer alan maddelerin ayırt ediciliklerini hesaplamak için madde-toplam korelasyonu kullanılmıştır. ÖEIYABÖ' ne ait her bir maddeye ilişkin madde-toplam korelasyon değerleri Tablo 5 'te sunulmuştur.

Tablo 5.

ÖEİGDİABÖ'nün Madde-Toplam Korelasyonları Değerleri

\begin{tabular}{lcc}
\hline & & Ayrrt \\
Boyutlar & Madde & $\begin{array}{c}\text { Edicilik } \\
\text { İndeksi }\end{array}$ \\
\hline & V12 & .733 \\
& V15 & .763 \\
V20 & .718 \\
V22 & .705 \\
Toplumsal & V33 & .754 \\
& V34 & .745 \\
& V36 & .697 \\
& V37 & .768 \\
& V38 & .752 \\
& V39 & .791 \\
Ekonomik & V40 & .791 \\
& V26 & .740 \\
& V27 & .679 \\
V28 & .689 \\
Bireysel & V29 & .693 \\
& V30 & .583 \\
Siyasal & V32 & .690 \\
\hline & V1 & .519 \\
& V2 & .463 \\
& V3 & .587 \\
& V8 & .689 \\
\hline & V16 & .748 \\
V17 & .724 \\
& V18 & .560 \\
& V19 & .748 \\
\hline
\end{tabular}


Tablo 5 incelendiğinde madde toplam korelasyonuna ilişkin değerler ölçeğin toplumsal boyutu için .791-.697 arasında ekonomik boyutu için .740-.583 arasında, bireysel boyutu için .689-.463 arasında ve siyasal boyutu için ise .748.560 arasında değiştiği görülmektedir. Madde toplam korelasyonunun yorumlanmasında değeri .30 ve üzerinde olan maddelerin iyi derecede ayırt edici özelliğe sahip olduğu söylenmektedir (Büyüköztürk, 2008). Tablo 5'te elde edilen değerlere göre ölçekte yer alan maddelerin tamamı yeterli düzeyde ayırt edici olduğu sonucuna ulaşılabilir.

\section{Verilerin Analizi}

Araştırma verilerinin analizinde SPSS.21 paket programından faydalanılmıştır. Araştırmaya ilişkin elde edilen verilerin analizinden önce dağılımın homojen olup olmadığını test eden Levene'nin Varyansların Homojenliği Testi sonuçlarına bakılmış, araştırmada varyansların homojenliği varsayımının karşılandığı belirlenmiştir $(\mathrm{F}=0,698, \mathrm{p}>0.05)$. Çalışmada verilerin normal dağılım gösterip göstermediğine Kolmogorov-Smirnov testi ile bakılmış, verilerin normal dağılım gösterdiği tespit edilmiştir (Kolmogorov-Smirnov z=0,200 p>0.05). Araştırmada normallik dağılımı ve varyansların homojenliği varsayımları yerine getirildiğinden, araştırmada parametrik testler kullanılmıştır. Öğretmenlerin ölçek maddelerine verdikleri yanıtların cinsiyet, okul türü, değişkenine göre farklılık gösterip göstermediğini belirlemek için $t$ testi, mesleki kıdem ve görev yapılan okul kademesi ve mezun olunan okul türü değişkenlerine göre farklılık gösterip göstermediğini belirlemek amacıyla Tek Yönlü Varyans Analizi (ANOVA) ve gruplar arası farklılığı belirlemek için ise LSD testi yapılmıştır.

\section{Bulgular}

Bu bölümde araştırma verilerinden elde edilen bulgular alt amaçlar doğrultusunda sırasıyla verilmiştir.

\section{Eğitimin Bireysel İşlevlerinin Gerçekleşmesine İlişkin Öğretmenlerin Alg1 Düzeyleri}

Araştırmanın cevap aradığı birinci soru öğretmenlerin eğitimin işlevlerinden bireysel işlevine yönelik algı düzeylerini ortaya koymaktır. Bu amaçla öğretmen görüşlerinden elde edilen bulgular Tablo 6 ' da verilmiştir.

Tablo 6 incelendiğinde, öğretmenlerin eğitimin bireysel işlevlerini yerine getirmesi ile ilgili algılarının katılıyorum düzeyinde $(X=3.54)$ olduğu görülmektedir. Öğretmenlerin eğitimin bireysel işlevlerine yönelik vermiş oldukları cevapların en yüksek ortalaması eğitimin bireyleri zihinsel anlamda geliştirdiği $(X=3.75$, ) maddesi iken, bunu sırasıyla bireyleri sosyal $(X=3.69)$ ve duygusal $(X=3.48)$ anlamda geliştirdiği maddeleri izlemektedir. Öğretmenlerin alg1 düzeylerindeki en düşük ortalamanın bireyin niteliğini artırma $(X=3.28)$ maddesi olduğu görülmektedir. 
Tablo 6.

Öğretmenlerin Eğitimin Bireysel İşlevlerine Yönelik Algi Düzeyleri

\begin{tabular}{clcccc}
\hline Madde No & \multicolumn{1}{c}{ Maddeler } & $X$ & Ss & Katılım Düzeyi \\
\hline 1 & $\begin{array}{l}\text { Eğitim kurumları bireyleri sosyal anlamda } \\
\text { geliştirmektedir. }\end{array}$ & 3.69 & 1.02 & Katılıyorum \\
2 & $\begin{array}{l}\text { Eğitim kurumları bireyleri zihinsel anlamda } \\
\text { geliştirmektedir. }\end{array}$ & 3.75 & 0.91 & Katılıyorum \\
3 & $\begin{array}{l}\text { Eğitim kurumları bireyleri duygusal anlamda } \\
\text { geliştirmektedir. }\end{array}$ & 3.48 & 0.99 & Katılıyorum \\
4 & $\begin{array}{l}\text { Eğitim kurumları bireylerin niteliğini } \\
\text { artırmaktadır. }\end{array}$ & 3.28 & 0.97 & Kararsızım \\
\hline & Toplam & 3.54 & 0.80 & Katılıyorum \\
\hline
\end{tabular}

Eğitimin Toplumsal İşlevlerini Yerine Getirmeye İlişkin Öğretmenlerin Alg1 Düzeyleri

Araştırmanın cevap aradığı ikinci soru öğretmenlerin eğitimin işlevlerinden toplumsal işlevlevine yönelik alg1 düzeylerini ortaya koymaktır. $\mathrm{Bu}$ amaçla öğretmen görüşlerinden elde edilen bulgular Tablo 7'te verilmiştir.

Tablo 7.

Öğretmenlerin Ĕ̆itimin Toplumsal İşlevlerine Yönelik Algi Düzeyleri

\begin{tabular}{|c|c|c|c|c|}
\hline Madde No & Maddeler & $\overline{\mathrm{X}}$ & Ss & Katılım Düzeyi \\
\hline 1 & $\begin{array}{l}\text { Eğitim kurumları topluma uyumlu bireyler } \\
\text { yetiştirmektedir. }\end{array}$ & 3.27 & 0.94 & Kararsızım \\
\hline 2 & $\begin{array}{l}\text { Eğitim kurumları farklı dine inanan insanların } \\
\text { bir arada yaşamasını sağlayacak davranışları } \\
\text { bireylere kazandırmaktadır. }\end{array}$ & 3.17 & 0.95 & Kararsızım \\
\hline 3 & $\begin{array}{l}\text { Eğitim kurumları farklı etnik grupların birlikte } \\
\text { yaşamasını sağlayacak davranışları bireylere } \\
\text { kazandırmaktadır. }\end{array}$ & 3.37 & 0.93 & Kararsızım \\
\hline 4 & $\begin{array}{l}\text { Eğitim kurumları milli değerleri bireylere } \\
\text { aktarmaktadır. }\end{array}$ & 3.61 & 0.97 & Katıllyorum \\
\hline 5 & $\begin{array}{l}\text { Eğitim kurumları toplumdaki norm, değer ve } \\
\text { davranış kalıplarını benimsemiş bireyler } \\
\text { yetiştirmektedir. }\end{array}$ & 3.16 & 0.98 & Kararsızım \\
\hline 6 & $\begin{array}{l}\text { Ĕgitim kurumları bireyleri gelecekteki } \\
\text { toplumsal rollerine uygun şekilde } \\
\text { yetiştirmektedir. }\end{array}$ & 2.95 & 1.02 & Kararsızım \\
\hline 7 & $\begin{array}{l}\text { Eğitim kurumları Türkçeyi düzgün ve doğru } \\
\text { kullanan bireyler yetiştirmektedir. }\end{array}$ & 3.13 & 1.08 & Kararsızım \\
\hline 8 & $\begin{array}{l}\text { Eğitim kurumları kültürün öğelerini bireylere } \\
\text { etkin bir şekilde aktarmaktadır. }\end{array}$ & 3.15 & 1.03 & Kararsızım \\
\hline 9 & $\begin{array}{l}\text { Eğitim kurumları küresel değerleri bilen } \\
\text { bireyleri yetiştirmektedir. }\end{array}$ & 2.99 & 1.01 & Kararsızım \\
\hline 10 & $\begin{array}{l}\text { Eğitim kurumları sosyal bütünleşmeyi } \\
\text { sağlamaktadır. }\end{array}$ & 3.31 & 0.96 & Kararsızım \\
\hline 11 & $\begin{array}{l}\text { Eğitim kurumları kültürel bütünleşmeyi } \\
\text { sağlamaktadır. }\end{array}$ & 3.31 & 0.97 & Kararsızım \\
\hline & Toplam & 3.21 & 0.79 & Kararsızım \\
\hline
\end{tabular}


Tablo 7 incelendiğinde, öğretmenlerin eğitimin toplumsal işlevlerini yerine getirmesi ile ilgili algılarının kararsızım düzeyinde $(X=3.21)$ olduğu görülmektedir. Öğretmenlerin eğitimin toplumsal işlevlerine yönelik en olumlu algılarının milli değerleri bireylere aktarma $(\bar{X}=3,61)$ olarak katılıyorum düzeyinde olduğu görülmektedir. Bunun dışındaki tüm maddelere yönelik algılarının kararsızım şeklinde çıktığı görülmektedir. Bunlar sırasıyla farklı etnik grupların birlikte yaşamasını sağlayacak davranışları bireylere kazandırma $(X=3.37)$, sosyal bütünleşmeyi sağlama $(X=3.31)$, kültürel bütünleşmeyi sağlama $(X=3.31)$, topluma uyumlu bireyler yetiştirme $(X=3.27)$, farklı dine inanan insanların bir arada yaşamasını sağlayacak davranışları bireylere kazandırma topluma uyumlu bireyler yetiştirme $(X=3.17)$, toplumdaki norm, değer ve davranış kalıplarını benimsemiş bireyler yetiştirme $(X=3.16)$, kültürün öğelerini bireylere etkin bir şekilde aktarma $(X=3.15)$, Türkçeyi düzgün ve doğru kullanan bireyler yetiştirme $(X=3.13)$ ve küresel değerleri bilen bireyleri yetiştirme $(X=2.99)$ olduğu görülmektedir. Öğretmenlerin eğitimin toplumsal işlevine yönelik algılarında bireyleri gelecekteki toplumsal rollerine uygun şekilde yetiştirme $(X=2.95)$ en düşük düzey olarak kararsızım şeklindedir.

\section{Ĕ̆itimin Ekonomik İşlevlerinin Gerçekleşme Düzeyine İlişkin Öğretmenlerin}

\section{Alg1 Düzeyleri}

Araştırmanın cevap aradığı ikinci soru öğretmenlerin eğitimin işlevlerinden ekonomik işlevlerine yönelik alg1 düzeylerini ortaya koymaktır. $\mathrm{Bu}$ amaçla öğretmen görüşlerinden elde edilen bulgular Tablo 8'de verilmiştir.

Tablo 8.

Öğretmenlerin Eğitimin Ekonomik Isşlevlerine Yönelik Algi Düzeyleri

\begin{tabular}{clccc}
\hline Madde No & \multicolumn{1}{c}{ Maddeler } & $\overline{\mathrm{X}}$ & Ss & Katılım Düzeyi \\
\hline 1 & $\begin{array}{l}\text { Eğitim kurumları teknolojik yönden çă̆a } \\
\text { uygun becerileri kazandırmaktadır. }\end{array}$ & 3.18 & 1.02 & Kararsızım \\
2 & $\begin{array}{l}\text { Eğitim kurumları ekonomi kurumlarını } \\
\text { istediği nitelikte bireyler yetiştirmektedir. }\end{array}$ & 2.90 & 1.02 & Kararsızım \\
3 & $\begin{array}{l}\text { Eğitim kurumları ekonomi kurumunun } \\
\text { istediği nicelikte bireyler yetiştirmektedir. }\end{array}$ & 2.82 & 0.96 & Kararsızım \\
4 & $\begin{array}{l}\text { Eğitim kurumları mesleki yeterliliğe sahip } \\
\text { bireyler yetiştirmektedir. }\end{array}$ & 2.76 & 1.04 & Kararsızım \\
& $\begin{array}{l}\text { Eğitim kurumları istihdam problemi } \\
\text { yaşamayacak alanlarda bireyler }\end{array}$ & 2.43 & 1.02 & Katılmıorum \\
yetiştirmektedir. & $\begin{array}{l}\text { Eğitim kurumları rekabet gücü yüksek } \\
\text { bireyler yetiştirmektedir. }\end{array}$ & 2.97 & 1.05 & Kararsızım \\
\hline 6 & Toplam & 2.83 & 0.83 & Kararsızım \\
\hline
\end{tabular}

Tablo 8 incelendiğinde, eğitimin ekonomik işlevlerini yerine getirmesi ile ilgili öğretmen algılarının kararsızım düzeyinde $(X=2.83)$ olduğu görülmektedir. Öğretmenlerin eğitimin ekonomik işlevlerine yönelik en yüksek algılarının teknolojik yönden çağa uygun becerileri kazandırma $(X=3,18)$ olduğu, bunu sirasiyla rekabet gücü yüksek bireyler yetiştirme $(X=2.97)$ ile ekonomi kurumlarının istediği nitelikte bireyler yetiştirme $(X=2,90)$ takip ettiği görülmektedir. Öğretmenlerin eğitimin ekonomik 
işlevine yönelik en düşük algılarının istihdam problemi yaşamayacak alanlarda bireyler yetiştirme $(X=2.43)$ maddesidir.

Eğitimin Siyasal İşlevlerinin Gerçekleşme Düzeyine İlişkin Öğretmenlerin Algı Düzeyleri

Araştırmanın cevap aradığ1 üçüncü soru öğretmenlerin eğitimin işlevlerinden siyasal işlevlevine yönelik algı düzeylerini ortaya koymaktır. Bu amaçla öğretmenlerden elde edilen bulgular Tablo 9'da verilmiştir.

Tablo 9.

Eğitimin Siyasal İşlevlerine Yönelik Algı Düzeyleri

\begin{tabular}{clccc}
\hline $\begin{array}{l}\text { Madde } \\
\text { No }\end{array}$ & Maddeler & $\overline{\mathrm{X}}$ & Ss & Katılım Düzeyi \\
\hline 1 & $\begin{array}{l}\text { Eğitim kurumları bireylere } \\
\text { demokratik bilinç } \\
\text { kazandırmaktadır. }\end{array}$ & 3.29 & 0.97 & Kararsızım \\
2 & $\begin{array}{l}\text { Eğitim kurumları bilinçli seçmen } \\
\text { yetiştirmektedir. }\end{array}$ & 2.89 & 1.04 & Kararsızım \\
\multirow{2}{*}{3} & $\begin{array}{l}\text { Eğitim kurumları siyasi liderler } \\
\text { yetiştirmektedir. }\end{array}$ & 2.66 & 1.03 & Kararsızım \\
4 & $\begin{array}{l}\text { Eğitim kurumları bilinçli yönetici } \\
\text { yetiştirmektedir. }\end{array}$ & 2.78 & 1.02 & Kararsızım \\
\hline & Toplam & 2.90 & 0.86 & Kararsızım \\
\hline
\end{tabular}

Tablo 9 incelendiğinde, öğretmenlerin eğitimin siyasal işlevlerini yerine getirmesi ile ilgili algılarının kararsızım düzeyinde $(X=2.90)$ olduğu görülmektedir. Öğretmenler tüm maddelerde kararsızım şeklinde görüş belirtmişlerdir. Öğretmenlerin eğitimin siyasal işlevlerine yönelik en yüksek algılarının bireylere demokratik bilinç kazandırma $(X=3,29)$ olduğu, siyasi liderler yetiştirmenin $(X=2.66)$ öğretmen algıları açısından en düşük düzeyde olduğu görülmektedir. Siyasal işlevlerle ilgili bilinçli seçmen yetiştirme $(X=2.89)$ ve bilinçli yönetici yetiştirme $(X=2,78)$ ile ilgili öğretmen algılarının da kararsızım düzeyinde olduğu görülmektedir.

Öğretmenlerin Eğitimin İşlevlerinin Gerçekleşme Düzeylerine Yönelik Görüşlerinin Cinsiyet, Okul Türü, Okul Kademesi, Mezun Olunan Okul Türü Değişkenine Göre Anlamlı Olarak Farklılılaşıp Farklılaşmadağını Belirlemeye Yönelik Yapılan Analizlerden Elde Edilen Bulgular

Öğretmenlerin ÖEİGDİABÖ'ye yönelik algı düzeylerinde cinsiyet değişkenine göre farklılaşma olup olmadığını belirlemek için yapılan bağımsız örneklem ti-testi sonuçları Tablo 10'da verilmiştir. 
Tablo 10.

Cinsiyet Değiş̧kenine Göre Öğretmenlerin Algı Düzeyleri

\begin{tabular}{|c|c|c|c|c|c|c|c|}
\hline Boyutlar & Cinsiyet & $\mathrm{N}$ & $\bar{X}$ & Ss & $\mathrm{Sd}$ & $\mathrm{t}$ & $\mathrm{p}$ \\
\hline \multirow{2}{*}{ Bireysel } & Kadın & 146 & 3.61 & 0.77 & \multirow{10}{*}{416} & \multirow{2}{*}{1.16} & \multirow{2}{*}{0.24} \\
\hline & Erkek & 272 & 3.51 & 0.81 & & & \\
\hline \multirow{2}{*}{ Toplumsal } & Kadın & 146 & 3.39 & 0.78 & & & \\
\hline & Erkek & 272 & 3.11 & 0.78 & & 3.42 & 0.00 \\
\hline \multirow{2}{*}{ Ekonomik } & Kadın & 146 & 3.06 & 0.80 & & & \\
\hline & Erkek & 272 & 2.72 & 0.81 & & 4.08 & 0.00 \\
\hline \multirow{2}{*}{ Siyasal } & Kadın & 146 & 3.05 & 0.85 & & & \\
\hline & Erkek & 272 & 2.82 & 0.85 & & 2.58 & 0.01 \\
\hline \multirow{2}{*}{ Toplam } & Kadın & 146 & 3.28 & 0.71 & & & \\
\hline & Erkek & 272 & 3.04 & 0.71 & & 3.31 & 0.00 \\
\hline
\end{tabular}

Öğretmenlerin eğitimin işlevlerini yerine getirmesiyle ilgili algı düzeylerinin cinsiyet değişkenine göre istatistiksel olarak anlamlık gösterip göstermediğini tespit etmek için bağımsız gruplar t-testi uygulanmıştır. Analiz sonucuna göre eğitimin işlevlerini değerlendirmesine yönelik öğretmenlerin algıları cinsiyet değişkenine göre ölçeğin bireysel alt boyutunda anlamlı olarak farklılaşmazken ( $p>.05)$; toplumsal, ekonomik, siyasal alt boyutları ile ölçeğin toplamında farklılaşmamaktadır $(\mathrm{p}<.05)$. Farklılaşma kadın lehine gerçekleşmiştir.

Öğretmenlerin ÖEİGDİABÖ'ye yönelik algı düzeylerinin okul türü değişkenine göre puanlarında farklılaşma olup olmadığını belirlemek için yapılan bağımsız örneklem titesti sonuçları Tablo $11^{\prime}$ de verilmiştir.

Tablo 11.

Okul Türü Değişkenine Göre Öğretmenlerin Algı Düzeyleri

\begin{tabular}{|c|c|c|c|c|c|c|c|}
\hline Boyutlar & $\begin{array}{l}\text { Okul } \\
\text { Türü }\end{array}$ & $\mathrm{N}$ & $\bar{X}$ & $S$ & $\mathrm{Sd}$ & $\mathrm{t}$ & $\mathrm{p}$ \\
\hline \multirow{2}{*}{ Bireysel } & Özel & 78 & 3.83 & 0.59 & 3.51 & & \\
\hline & Devlet & 340 & 3.48 & 0.82 & 4.31 & 4.31 & 0.00 \\
\hline \multirow{2}{*}{ Toplumsal } & Özel & 78 & 3.54 & 0.71 & 4.05 & & \\
\hline & Devlet & 340 & 3.14 & 0.79 & 4.33 & 4.33 & 0.00 \\
\hline \multirow{2}{*}{ Ekonomik } & Özel & 78 & 3.08 & 0.89 & 2.82 & & \\
\hline & Devlet & 340 & 2.78 & 0.80 & 2.64 & 2.64 & 0.01 \\
\hline \multirow{2}{*}{ Siyasal } & Özel & 78 & 3.02 & 0.84 & 1.40 & & \\
\hline & Devlet & 340 & 2.87 & 0.86 & 1.42 & 1.42 & 0.16 \\
\hline \multirow{2}{*}{ Toplam } & Özel & 78 & 3.41 & 0.65 & 3.73 & & \\
\hline & Devlet & 340 & 3.06 & 0.72 & 3.97 & 3.97 & 0.00 \\
\hline
\end{tabular}

Öğretmenlerin eğitimin işlevlerini yerine getirmesiyle ilgili alg1 düzeylerinde okul türü değişkenine göre istatistiksel olarak anlamlılık gösterip göstermediği tespit etmek için bağımsız gruplar t-testi uygulanmıstır. Analiz sonucuna göre eğitimin işlevlerini değerlendirmesine yönelik öğretmenlerin algıları okul türü değişkenine göre ölçeğin siyasal alt boyutunda anlamlı bir şekilde farklılaşmazken ( $\mathrm{p}>.05$ ), bireysel, toplumsal, ekonomik alt boyutları ile ölçeğin toplamında istatistiksel olarak kadın lehine anlamlı bir şekilde farklılık göstermektedir $(\mathrm{p}<.05)$. 
Öğretmenlerin ÖEİGDİABÖ'ye yönelik alg1 düzeylerinde okul kademesi değişkenine göre puanlarında farklılaşma olup olmadığını belirlemek için yapılan ANOVA testi sonuçları Tablo 12' de verilmiştir.

Tablo 12.

Okul Kademesi Değişkenine Göre Öğretmenlerin Algi Düzeyleri

\begin{tabular}{|c|c|c|c|c|c|c|c|}
\hline Boyutlar & Kademe & $\mathrm{N}$ & $\bar{x}$ & SS & F & Sig. & $\begin{array}{l}\text { Anlamlı } \\
\text { Fark }\end{array}$ \\
\hline \multirow{4}{*}{ Bireysel } & İlkokul & 142 & 3.64 & 0,77 & \multirow{4}{*}{3.16} & \multirow{4}{*}{0.04} & \multirow{4}{*}{$\begin{array}{l}\text { İlkokul- } \\
\text { lise }\end{array}$} \\
\hline & Ortaokul & 139 & 3.58 & 0.77 & & & \\
\hline & Lise & 137 & 3.41 & 0.83 & & & \\
\hline & Toplam & 418 & 3.54 & 0.80 & & & \\
\hline \multirow{4}{*}{ Toplumsal } & İlkokul & 142 & 3.33 & 0.79 & \multirow{4}{*}{5.67} & \multirow{4}{*}{0.00} & \multirow{4}{*}{$\begin{array}{l}\text { İlkokul- } \\
\text { lise } \\
\text { Ortaokul- } \\
\text { lise }\end{array}$} \\
\hline & Ortaokul & 139 & 3.28 & 0.79 & & & \\
\hline & Lise & 137 & 3.03 & 0.76 & & & \\
\hline & Toplam & 418 & 3.21 & 0.79 & & & \\
\hline \multirow{4}{*}{ Ekonomik } & İlkokul & 142 & 2.97 & 0.86 & \multirow{4}{*}{3.83} & \multirow{4}{*}{0.02} & \multirow{4}{*}{$\begin{array}{l}\text { İlkokul- } \\
\text { lise }\end{array}$} \\
\hline & Ortaokul & 139 & 2.85 & 0.83 & & & \\
\hline & Lise & 137 & 2.69 & 0.75 & & & \\
\hline & Toplam & 418 & 2.84 & 0.82 & & & \\
\hline \multirow{4}{*}{ Siyasal } & İlkokul & 142 & 3.03 & 0.87 & \multirow{4}{*}{6.84} & \multirow{4}{*}{0.00} & \multirow{4}{*}{$\begin{array}{l}\text { İlkokul- } \\
\text { lise } \\
\text { Ortaokul- } \\
\text { lise }\end{array}$} \\
\hline & Ortaokul & 139 & 2.99 & 0.84 & & & \\
\hline & Lise & 137 & 2.68 & 0.82 & & & \\
\hline & Toplam & 418 & 2.90 & 0.85 & & & \\
\hline \multirow{4}{*}{ Toplam } & İlkokul & 142 & 3.25 & 0.72 & \multirow{4}{*}{6.40} & \multirow{4}{*}{0.00} & \multirow{4}{*}{$\begin{array}{l}\text { İlkokul- } \\
\text { lise } \\
\text { Ortaokul- } \\
\text { lise }\end{array}$} \\
\hline & Ortaokul & 139 & 3.18 & 0.71 & & & \\
\hline & Lise & 137 & 2.95 & 0.68 & & & \\
\hline & Toplam & 418 & 3.13 & 0.71 & & & \\
\hline
\end{tabular}

Okul kademesi değişkenine göre öğretmenlerin eğitimin işlevlerini yerine getirmeye ilişkin algı düzeylerini karşılaştırmak için ANOVA testi kullanılmıştır. Analiz sonucuna göre öğretmenlerin algıları okul kademesi değişkenine göre ölçeğin bireysel, toplumsal, ekonomik ve siyasal alt boyutları ile ölçeğin tamamına göre anlamlı bir farklılık göstermektedir $(\mathrm{p}<.05)$. Diğer bir ifadeyle öğretmenlerin eğitimin işlevlerini gerçekleştirmesine ilişkin algıları gerek ölçeğin alt boyutları gerekse bütünü açısından anlamlı biçimde farklılaşmaktadır. Farklıı̆ı̆ın kaynağı incelendiğinde bireysel boyutta ilkokul-lise arasında ilkokul lehine, toplumsal boyutta ilkokul- lise arasında ilkokul lehine, ortaokul-lise arasında ortaokul lehine, ekonomik boyutta ilkokul-lise arasında ilkokul lehine, siyasal boyutta ilkokul-lise arasında ilkokul lehine, ortaokul-lise arasında ortaokul lehine, toplamda ise ilkokul-lise arasında ilkokul lehine, ortaokul-lise arasında ortaokul lehine olduğu görülmektedir.

Öğretmenlerin ÖEİGDİABÖ'ye yönelik alg1 düzeylerinde kıdem değişkenine göre puanlarında farklılaşma olup olmadığını belirlemek için yapılan ANOVA testi sonuçları Tablo 13'te verilmiştir. 
Tablo 13.

Kidem Değişkenine Göre Öğretmenlerin Algi Düzeyleri

\begin{tabular}{|c|c|c|c|c|c|c|c|}
\hline Boyutlar & Kidem & $\mathrm{N}$ & $\bar{x}$ & SS & $\mathrm{F}$ & Sig. & Anlamlı Fark \\
\hline \multirow{7}{*}{ Bireysel } & $0-5$ yil & 54 & 3.64 & 0.77 & \multirow{7}{*}{0.75} & \multirow{7}{*}{0.55} & \multirow{7}{*}{ 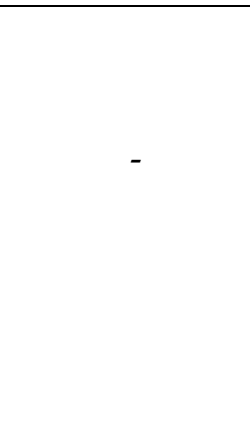 } \\
\hline & 6-11 yıl & 79 & 3.64 & 0.68 & & & \\
\hline & $\begin{array}{l}12-17 \\
\text { y1l }\end{array}$ & 90 & 3.51 & 0.83 & & & \\
\hline & $\begin{array}{l}18-22 \\
\text { y1l }\end{array}$ & 107 & 3.52 & 0.80 & & & \\
\hline & 23 yil & & 2,17 & & & & \\
\hline & üzeri & 00 & $0 . T^{\prime}$ & 0.00 & & & \\
\hline & Toplam & 418 & 3.54 & 0.80 & & & \\
\hline \multirow{6}{*}{ Toplumsal } & $0-5$ yil & 54 & 3.59 & 0.71 & \multirow{6}{*}{7.04} & \multirow{6}{*}{0.00} & \multirow{6}{*}{$\begin{array}{l}0-5 \text { yıl-12-17 yıl } \\
0-5 \text { yıl-18-22 yıl } \\
0-5 \text { y1l-23 y1l ve } \\
\text { üzeri } \\
6-11 \text { yıl-23 yıl } \\
\text { ve üzeri }\end{array}$} \\
\hline & $6-11$ yil & 79 & 3.39 & 0.72 & & & \\
\hline & $\begin{array}{l}12-17 \\
\text { y1l }\end{array}$ & 90 & 3.19 & 0.73 & & & \\
\hline & $\begin{array}{l}18-22 \\
\text { y1l }\end{array}$ & 107 & 3.13 & 0.78 & & & \\
\hline & $\begin{array}{l}23 \text { yll } \\
\text { ve }\end{array}$ & 88 & 2.95 & 0.85 & & & \\
\hline & üzeri & & & & & & \\
\hline \multirow{7}{*}{ Ekonomik } & 05 wal & 54 & 3.21 & 0.82 & & & \multirow{7}{*}{$\begin{array}{l}0-5 \text { y1l-18-22 yıl } \\
0-5 \text { yll-23 yıl ve } \\
\text { üzeri }\end{array}$} \\
\hline & 6-11 yıl & 79 & 2.97 & 0.76 & & & \\
\hline & $\begin{array}{l}12-17 \\
\text { y1l }\end{array}$ & 90 & 2.81 & 0.76 & & & \\
\hline & $\begin{array}{l}18-22 \\
\text { y1l } \\
23 \text { y1l }\end{array}$ & 107 & 2.74 & 0.86 & 3.41 & 0.01 & \\
\hline & ve & 88 & 2.68 & 0.82 & & & \\
\hline & üzeri & & & & & & \\
\hline & Toplam & 418 & 2.83 & 0.82 & & & \\
\hline \multirow{6}{*}{ Siyasal } & $0-5$ y1l & 54 & 3.14 & 0.85 & & & \multirow{6}{*}{$\begin{array}{l}0-5 \text { y1l-23 yıl ve } \\
\text { üzeri }\end{array}$} \\
\hline & 6-11 yıl & 79 & 2.98 & 0.82 & & & \\
\hline & $\begin{array}{l}12-17 \\
\text { y1l }\end{array}$ & 90 & 2.91 & 0.85 & & & \\
\hline & $\begin{array}{l}18-22 \\
\text { y1l }\end{array}$ & 107 & 2.89 & 0.84 & 2.63 & 0.03 & \\
\hline & $\begin{array}{l}23 \text { yil } \\
\text { ve } \\
\text { üzeri }\end{array}$ & 88 & 2.69 & 0.88 & & & \\
\hline & Toplam & 418 & 2.90 & 0.86 & & & \\
\hline \multirow{6}{*}{ Toplam } & $0-5$ y1l & 54 & 3.43 & 0.69 & & & \multirow{6}{*}{$\begin{array}{l}0-5 \text { y1l-18-22 y1l } \\
0-5 \text { y1l-23 yıl ve } \\
\text { üzeri } \\
6-11 \text { yıl-23 yıl } \\
\text { ve üzeri }\end{array}$} \\
\hline & 6-11 yıl & 79 & 3.26 & 0.64 & & & \\
\hline & $\begin{array}{l}12-17 \\
\text { y1l }\end{array}$ & 90 & 3.10 & 0.67 & & & \\
\hline & $\begin{array}{l}18-22 \\
\text { y1l } \\
23 \text { y1l }\end{array}$ & 107 & 3.06 & 0.73 & 5,00 & 0.00 & \\
\hline & & 88 & 2.93 & 0.76 & & & \\
\hline & $\begin{array}{l}\text { üzeri } \\
\text { Toplam }\end{array}$ & 418 & 3.12 & 0.72 & & & \\
\hline
\end{tabular}


Analiz sonucuna göre öğretmenlerin algıları ölçeğin bireysel boyutunda anlamlı bir farklılık göstermezken ( $\mathrm{p}>.05)$, toplumsal, ekonomik ve siyasal alt boyutları ile ölçeğin tamamı açısından anlamlı bir farklılık göstermektedir $(p<.05)$. Diğger bir ifadeyle öğretmenlerin eğitimin işlevlerini gerçekleştirmesine ilişkin algıları kıdem değişkeni açısından ölçeğin toplumsal, siyasal, ekonomik ve ölçeğin toplam açısından farklılık varken bireysel alt boyutunda farklılık bulunmamaktadır. Bu fark toplumsal boyutta 05 yıl ile 12-17, 18-22 ve 23 yıl ve üzerinde 0-5 yılı lehine, 6-11 yıl ile 23 yıl ve üzerinde 611 yılı lehinedir. Ekonomik boyutta $0-5$ y1lı ile $18-22$ ve 23 y1l ve üzerinde $0-5$ y1lı lehinedir. Siyasal boyutta $0-5$ y1lları ile 23 yıl ve üzerinde $0-5$ y1lı lehinedir. Toplamda ise, $0-5$ yılı ile 18-22 yılı ve 23 yıl ve üzerinde $0-5$ yılı lehine, 6-11 yılı ile 23 yıl ve üzerinde 6-11 y1lı lehinedir.

Öğretmenlerin ÖEİGDİABÖ'ye yönelik alg1 düzeylerinin mezun olunan okul türü değişkenine göre puanlarında farklılaşma olup olmadığını belirlemek için yapılan ANOVA testi sonuçları Tablo 14'te verilmiştir.

Tablo 14.

Mezun Olunan Okul Türüne Göre Öğretmenlerin Algı Düzeyleri

\begin{tabular}{|c|c|c|c|c|c|c|c|}
\hline Boyutlar & Eğitim & $\mathrm{N}$ & $\bar{x}$ & SS & $\mathrm{F}$ & & Sig. \\
\hline \multirow{4}{*}{ Bireysel } & Lisans & 285 & 3.49 & 0.85 & \multirow{4}{*}{1.43} & & \multirow{4}{*}{0.23} \\
\hline & Lisansüstü & 82 & 3.67 & 0.69 & & & \\
\hline & Diğer & 51 & 3.5 & 0.76 & & & \\
\hline & Toplam & 418 & 3.55 & 0.80 & & & \\
\hline \multirow{4}{*}{ Toplumsal } & Lisans & 285 & 3.22 & 0.81 & \multirow{4}{*}{2.06} & & \multirow{4}{*}{0.11} \\
\hline & Lisansüstü & 82 & 3.27 & 0.78 & & & \\
\hline & Diğer & 51 & 2.98 & 0.79 & & & \\
\hline & Toplam & 418 & 3.22 & 0.79 & & & \\
\hline \multirow{4}{*}{ Ekonomik } & Lisans & 285 & 2.80 & 0.80 & \multirow{4}{*}{0.85} & & \multirow{4}{*}{0.47} \\
\hline & Lisansüstü & 82 & 2.94 & 0.86 & & & \\
\hline & Diğer & 51 & 2.79 & 0.87 & & & \\
\hline & Toplam & 418 & 2.84 & 0.83 & & & \\
\hline \multirow{4}{*}{ Siyasal } & Lisans & 285 & 2.89 & 0.86 & \multirow{4}{*}{1.19} & \multirow{4}{*}{0.31} & \\
\hline & Lisansüstü & 82 & 3 & 0.88 & & & \\
\hline & Diğer & 51 & 2.74 & 0.78 & & & \\
\hline & Toplam & 418 & 2.90 & 0.86 & & & \\
\hline \multirow{4}{*}{ Toplam } & Lisans & 285 & 3.11 & 0.73 & \multirow{4}{*}{1.35} & \multirow{4}{*}{0.26} & \\
\hline & Lisansüstü & 82 & 3.21 & 0.73 & & & \\
\hline & Diğer & 51 & 2.99 & 0.69 & & & \\
\hline & Toplam & 418 & 3.13 & 0.72 & & & \\
\hline
\end{tabular}

Mezun olunan okul türü değişkenine göre öğretmenlerin eğitimin işlevlerini yerine getirmeye ilişkin alg1 düzeylerini karşılaştırmak için ANOVA testi kullanılmıştır. Analiz sonucuna göre ölçeğin bireysel, toplumsal, ekonomik, ve siyasal alt boyutları ile ölçeğin toplamına göre mezun olunan okul türü değişkeni açısından anlamlı bir farklılık göstermemektedir ( $>$.05). Diğer bir ifadeyle öğretmenlerin eğitimin işlevlerini 
gerçekleştirmesine ilişkin olarak gerek ölçeğin alt boyutları gerekse bütünü açısından anlamlı biçimde farklılaşmamaktadır.

\section{Tartışma, Sonuç ve Öneriler}

$\mathrm{Bu}$ çalışmada eğitimin işlevlerinin gerçekleşme düzeyleri, öğretmen algıları doğrultusunda incelenmiştir. Öğretmenlerin eğitimin toplumsal işlevlerini yerine getirmesi ile ilgili algılarının kararsızım düzeyinde olduğu sonucuna ulaşılmıştır. Maddeler bazında ise, sosyal bütünleşmeyi sağlama, kültürel bütünleşmeyi sağlama, topluma uyumlu bireyler yetiştirme, farklı dine inanan insanların bir arada yaşamasını sağlayacak davranışları bireylere kazandırma, topluma uyumlu bireyler yetiştirme, toplumdaki norm, değer ve davranış kalıplarını benimsemiş bireyler yetiştirme, kültürün öğelerini bireylere etkin bir şekilde aktarma, Türkçeyi düzgün ve doğru kullanan bireyler yetiştirme maddelerinde öğretmen algılarının kararsızım şeklinde ortaya çıtı̆̆ görülmektedir.

$\mathrm{Bu}$ sonuç, eğitimin toplumsal işlevlerini tam anlamıyla yerine getiremediği şeklinde yorumlanabilir. Eğitim kurumları, iş dünyasının ihtiyaçlarına göre programlarını ve ders içeriklerini belirlemeleri, eğitim toplumsal işlevlerine yön veren, toplumsal adalet, toplumsal dayanışma, kültürel değerler, fırsat eşitliği gibi kavramları geri plana alarak rekabetçilik ve girişimcilik gibi neoliberal kavramları ön plana çıkarmıştır (Sayılan, 2006). Bu durum öğretmenlerde eğitimin toplumsal işlevlerini yerine getiremediği şeklinde bir algının oluşmasına neden olmuş olabilir.

Öğretmenlerin eğitimin ekonomik işlevlerine yönelik en olumlu algılarının teknolojik yönden çağa uygun becerileri bireye kazandırma maddesi olduğu sonucuna ulaşılmıştır. Ö ğretmenlerin böyle düşünmelerinde son yapılan program değişikliğinde dijital ve teknolojik yetkinlik alanlarına yer verilmesi, robotik kodlama derslerinin ve STEM uygulamalarının varlığı öğretmenlerin düşüncelerini etkilemiş olabilir. Diğer taraftan Millî Eğitim Bakanlığı'nın teknolojik alt yapısındaki değişikler, sınıflarda akıllı tahtaların kurulması ve bilişim sınıflarının oluşturulması gibi uygulamalarda öğretmenlerin görüşlerini etkilemiş olabilir.

Öğretmenler, istihdam problemi yaşamayacak alanlarda bireylerin yetiştirildiğini düşünmemektedir.Öğretmenlerin böyle düşünmelerinde diplomalı işsizlik oranının yüksek olmasının (Eskicumalı, 2014) etkisi olabilir. Nitekim İçli'nin (2001), vurguladığı gibi, Türkiye'de eğitim kurumları sosyal ve ekonomik değişime ayak uyduramamış, bunun sonucunda, piyasanın talep ettiği sayı ve nitelikte iş gücü yetiştirmekte istenilen seviye yakalanamamıştır. Başka bir ifade ile Türk Eğitim Sisteminin işgücü piyasasının ihtiyaç duyduğu nitelikli elemanları yetiştiremediği söylenebilir. $\mathrm{Bu}$ durumun birçok nedeni olabilir. Bu nedenler içerisinde; eğitim kurumlarından mezun olan bireylerin edinmiş oldukları bilgi, beceri ve tutumların piyasanın talep ettiği özelliklerden çok farklı olması, mesleki okullaşmanın genel olarak geri planda kalması, mesleki eğitimin öneminin yeterince anlaşılamaması (İçli, 2001), bireylerin ilgi ve yeteneklerinin erken dönemde keşfedilerek buna uygun eğitim yapılamaması, eğitimin siyasal bir enstrüman haline gelerek popülist politikalar üretilmesi, üniversitelerde ihtiyaç bulunmayan bölümlere fazla öğrenci alınması gibi faktörler siralanabilir.

Eğitimden beklenilen işlevler, yalnızca kültürel mirasın genç kuşaklara aktarılması ve bireyin sosyalleşmesini sağlamak değil, bunun yanında iş gücünün 
değişen piyasa şartlarına uygun olarak nitelikli iş gücünü de temin etmesidir (Aygül, 2018). Diğer bir ifade ile, okullar bireylere, çağın gerektirdiği teknolojik bilgi ve becerileri kazandırarak ekonomik kalkınmayı gerçekleştirmeside beklenmektedir (Öztürk, 2005). Araştırmada öğretmenler, istihdam problemi yaşamayacak alanlarda bireylerin yetiştirildiğini düşünmediği şeklinde sonuçtan farklı olarak, Türk Eğitim Sisteminin piyasa taleplerine göre şekillendiğini bunun doğrultusunda piyasanın ihtiyaç duyduğu bireylerin yetiştirildiğini vurgulayan çalışmalar da bulunmaktadır. Şişman (2008) günümüzde bireylerin niteliğinin artırıldığı merkezler olarak görülen okullar, iş gücü piyasasının ihtiyaçları doğrultusunda mesleki eğitim veren kurumlar haline gelmiştir. Bunun sonucu olarak, eğitim politikaları piyasanın talepleri doğrultusunda şekillenmektedir (Şişman, 2008; Yıldız, 2008).

Öğretmenlerin eğitimin siyasal işlevlerini yerine getirmesi ile ilgili algılarının kararsızım düzeyinde olduğu sonucuna ulaşılmıştır. Eğitimin başlıca siyasal işlevlerinin; bireylere demokratik bilinç kazandırma, siyasi liderler yetiştirme, bilinçli seçmen yetiştirme, bilinçli yönetici yetiştirme, toplumun siyasal rejimini devam ettirme, insanları ülkelerinin ideoloji, değer ve hedeflerine ulaştırabilme, ülkenin siyasi düzenine bağlı vatandaşlar yetiştirme olduğu düşünüldüğünde, öğretmen görüşlerine göre eğitimin siyasal işlevlerini tam anlamıla yerine getiremediği söylenebilir. Öğretmenlerin böyle düşünmelerinde Can'1n da (2015) belirttiği gibi eğitim kurumlarının öncelikli amacının vatandaş yetiştirmekten çok piyasanın ihtiyaç duyduğu nitelikli eleman yetiştirmeye odaklanması, başka bir ifade ile eğitimin meslek edinmenin bir aracı haline gelmesinin etkisi olabilir.

Öğretmenler eğitimin bireylerin sosyal ve duygusal yöndende geliştirdiğini belirtmişlerdir. Araştırmanın bu sonucunu Doğan'ın (2014) yaptığı çalışmada bireylerin hayatlarının kolaylaştırılması ve zenginleştirilmesi için eğitimin bireysel işlevlerini yerine getirmesi gerektiği şeklindeki sonucu desteklemektedir.

Öğretmenlerin eğitimin işlevlerini yerine getirmesiyle ilgili algılarında okul türü değişkenine göre ölçeğin siyasal alt boyutunda anlamlı bir farklılık bulunmamıştır. Öğretmenlerin eğitimin siyasal işlevlerinin hem devlet okullarında hem de özel okullarda anlamlı farklılık olmamasının nedeni, her iki kurumun işleyişininde aynı mevzuata göre gerçekleşmesi ve denetimin MEB tarafından yapılmasından kaynaklanabilir.

Başka bir neden olarak, siyasal işlevler devletin ideolojik yapısını yansıttığı için gerek devlet okullarında gerekse özel okullarda Milli Eğitim Temel Kanununda ve öğretim programlarında belirlenen hedefler doğrultusunda bireyler yetiştirilme çabası gösterilebilir. Ayrıca, eğitim programında bulunması gereken özelliklerinden biri de programın değişmez ve genel olma özelliğidir. Bu kapsamda milli bayramlar, belirli gün ve haftalar vs. gibi belli konuların, Türkiye'de ki, resmi ve özel tüm okullarda işlenme zorunluluğu bulunmaktadır. 10 Kasım'1 içerisine alan haftada Türkiye' de ki, bütün okullarda Atatürk'ü anma etkinliklerinin yapılması buna örnek gösterilebilir. Türkiye de ki bütün eğitim kurumlarında Atatürk İlke İnkılâplarına bağlı, devletine karşı görev ve sorumluluklarını bilen, bayrağını, vatanını ve milletini seven, bireylerin yetiştirilmesi hedeflenmektedir (Sezer, 2018). Bu durum eğitimin siyasal işlevlerin yerine getirilmesine ilişkin öğretmen algılarının okul türü değişkeni açısından anlamlı farklılık göstermemesininin nedeni olarak gösterilebilir. 
Türkiye'de eğitim sistemi önemli ölçüde milli birliği güçlendirici şekilde; Atatürk İlkeleri ve İnkılâp Tarihi derslerinin üniversitelere kadar zorunlu ders olarak okutulması, tüm eğitim kurumlarına bayrağın kesintisiz olarak göndere çekilmesi, okulda yapılan törenler (Çanakkale Şehitlerini Anma, Cumhuriyet Bayramı), öğretim programlarının milli ideolojinin değerlerini aşılayacak şekilde oluşturulması (Çokgezen ve Terzi, 2008), öğretmenlerin eğitimin işlevlerini yerine getirmesiyle ilgili algılarının okul türü değişkenine göre siyasal işlevlerinde farklılık çıkmamasının diğer bir nedeni olarak gösterilebilir.

Araştırmada öğretmenlerin eğitimin işlevlerini gerçekleştirmesine ilişkin algılarının kıdem değişkeni açısından ölçeğin toplumsal, siyasal, ekonomik boyutlarında ve ölçeğin toplamında farklılık olduğu sonucuna ulaşılmıştır. Farklılık, mesleğe yeni başlayan öğretmenler ile meslekte 23 y1l ve üzerinde kıdeme sahip öğretmenler arasında gerçekleşmiştir. Bu farklılığın oluşmasının sebepleri olarak; meslekte belli bir tecrübe edinmiş öğretmenlerin, mesleğin henüz başında olan öğretmenlere oranla da fazla olumsuz deneyim yaşama ihtimalinin olması ve mesleki kıdem arttıkça mesleki yıpranmışlı̆̆ın ve tükenmişliğin artması gösterilebilir.

Genel olarak eğitimin toplumsal, ekonomik ve siyasal işlevlerine ilişkin öğretmen algılarının kararsızım şeklinde olması eğitim sisteminin yetersiz kaldı̆̆ şeklinde de yorumlanabilir. Bu durumun nedenleri; ideolojik yaklaşım, uzmanlardan yararlanamama, yönetimsel sorunlar, program geliştirme sorunları, birleştirilmiş sınıfların olması, sınıfların kalabalık olması, merkezi sınavların varlığı, öğrenci kişilik hizmetleriyle ilgili sorunlar, teftiş sorunları, öğretmenlerin örgütlenmesine ve ekonomik durumlarına ilişkin sorunlar, öğretmenlerin nitelik sorunu, taşımalı eğitim sorunu, bürokratik yapıdan kaynaklanan sorunlar, finansman sorunları, taşımalı eğitim sorunu mesleki ve teknik eğitim sorunu, öğretmen istihdamı sorunları şeklinde siralanabilir (Özyılmaz, 2013; Y1lmaz ve Altınkurt, 2011). Burada üzerinde durulmas1 gereken başka bir gerçek ise eğitim sisteminin bahsedilen bu sorunlarının çözümü adına yapılan değişikliklerin ve çabaların bütüncül bir sistem içinde ele alınmadığı (Gür ve Çelik, 2009), için istenilen sonuçların gerçekleşmemesidir. Bu araştırmanın sonuçlarına bağlı olarak şu önerilerde bulunulabilir.

Eğitimin ekonomik işlevlerinin yerine getirebilmesi için iş dünyası ve okullar iş birliği yapabilir. Bunun içinde gelecekte ihtiyaç duyulan iş gücü göz önünde bulundurularak öğrencilere bu doğrultuda eğitim verilmesine yönelik daha etkin çalışmalar yapılabilir. Nitelikli iş gücünü oluşturabilmek amacıyla Yükseköğretim öğrencilerinin edinmiş oldukları teorik bilgileri pratiğe dönüştürebilecekleri okul ve iş dünyasının birlikte yürütülebileceği programlar hazırlanabilir.

Bireylerin gelecekteki toplumsal rollerine uygun şekilde yetiştirilmesi için gerekli ortamlar sağlanabilir. Öğrencilere kendisinden beklenen rollere ilişkin sorumluluklar verilebilir.

Eğitimin siyasal işlevlerini yerine getirebilmesi için önderlik yeteneğine sahip bireylerin seçilip eğitilmesine yönelik çalışmalar yapılabilir. Okul meclis seçimi, sınıf başkanlığı seçimi gibi uygulamalarla bireylerde demokratik bilinci geliştirecek çalışmalara daha fazla yer verilebilir.

Bu çalışma, nicel yaklaşıma uygun olarak yürütülmüştür. Bu konuya ilişkin nitel çalışmalar yapılabilir. 
Eğitimin işlevlerinin yönelik öğretmenlerin algılarında nelerin etki ettiğine yönelik nitel ve nicel çalışmalar yapılabilir.

Türk eğitim sisteminin sorunları ile eğitimin işlevleri arasında ilişkisel araştırmalar yapilabilir.

Ĕ̆itimin işlevlerinin tam anlamıyla yerine getirilmesi için öğretmen önerilerinin neler olduğuna yönelik çalışmalar yapılabilir.

\section{Kaynakça}

Ada, Ş. ve Akan, D. (2007). Değişim sürecinde etkili okullar. Atatürk Üniversitesi Kazım Karabekir Eğitim Fakültesi Dergisi, (16), 343-373.

Adıgüzel, A. (2008). Ĕ̆̈itim faküllerinde öğretmen eğitimi program standartlarının gerçekleşme düzeyi. Doktora Tezi, Anadolu Üniversitesi, Eğitim Bilimleri Enstitüsü, Eskişehir.

Akın, F., Şimşek, O. ve Erdem, T. (2007). Türkiye'de eğitim sorunu, toplumsal aktörlerine göre eğitim sorunlarına bakış, Ankara: Türk Eğitim Sen Yayınları.

Avc1, M. (2012). Eğitimde temel bir sorun: Yabanc1laşma. Atatürk Üniversitesi Sosyal Bilimler Enstitüsü Dergisi, 16(3), 23-40.

Aydın, M. (1997). Kurumlar sosyolojisi. Ankara: Vadi Yayınları.

Aygül, H. H. (2018). Eğitime erişim, yoksulluk ve formel/enformel işgücü olarak üniversite gençliği: İstihdam için mi eğitim, eğitim için mi istihdam, Uluslararası Toplum Araştırmaları Dergisi. 8(8) 58-87. https:// doi.org/10.26466/opus.354859

Bal, A. P. ve Artut P. D. (2013). İlköğretim matematik öğretim programının değerlendirilmesi. Ĕ̆itim ve Öğretim Araştırmaları Dergisi, 2(4). 164-171.

Ballantine, J. H., Hammack, F. M. ve Stuber, J. (2017). The sociology of education: A systematic analysis. Routledge https:// doi.org/10.4324/9781315299914.

Barkan, S. (2013). Social problems: Continuity and change, Publisher: Flat World Knowledge, ISBN-10: 1453347208.

Başarır, F., Sarı, M. ve Çetin, A. (2014). Öğretmenlerin çok kültürlü eğitim algılarının incelenmesi, Pegem Eğitim ve Öğretim Dergisi, 4(2), 91-110. https:/ / doi.org/10.14527/pegegog.2014.011

Büyüköztürk, Ş. (2006). Sosyal bilimler için veri analizi el kitabı 6. Baskı, Ankara: Pegem A Yayıncilik.

Büyüköztürk, Ş. (2008). Veri analizi el kitabı: İstatistik, araştırma deseni, SPSS uygulamaları ve yorum. Ankara: Pegem-Akademi.

Can, İ. (2015). Değişen Türkiye' de eğitimin işlevlerini yeniden düşünmek: Velilerin ilk ve ortaokullardan beklentileri üzerine bir araştırma. Selçuk Üniversitesi Edebiyat Fakültesi Dergisi, (34), 247-266. https:/ / doi.org/10.21497/sefad.04674

Çetin A. ve Aydın S. (2019). Liselerin pansiyonunda nöbetçi öğretmen olmak: sorunlar ve çözüm önerileri. Gazi Üniversitesi Gazi Eğitim Fakültesi Dergisi, 39(3) , 1797-1825.

Çetin, A. ve Doğan, A. (2018). Bilim ve sanat merkezlerinde görev yapan matematik öğretmenlerinin karşılaştıkları sorunlar, Ankara Üniversitesi Ĕ̆itim Bilimleri Fakültesi Özel Ĕ̆itim Dergisi, 19(4) , 615641. https:/ / doi.org/10.21565/ozelegitimdergisi.370355 
Chakraborty, S., Chakraborty B., Singh Dahiya ve Timajo, L. (2018). Education as an instrument of social change and enhancing teaching-learning process with the help of technological development, Conference Paper May 2018.

Çakmak, Ö. (2008). Eğitimin ekonomiye ve kalkınmaya etkisi. Dicle Üniversitesi Ziya Gökalp Eğitim Fakültesi Dergisi, 11(2), 33-41.

Çokgezen, M. ve Terzi, N. (2008). Türkiye'de devletin eğitime müdahalesinin yeterli gerekçesi var mı? Liberal Düşünce, 13(49), 1-18.

Doğan, S. (2014). Eğitimin işlevleri. Celal Tayyar, U. (Ed.) Ĕ̆gitim bilimine giriş, içinde (39-53) İstanbul: Eğiten Kitap yayıncılık

Erden, M. (1998). Öğretmenlik mesleğine giriş, İstanbul: Alkım Yayınları.

Ertürk, S., (1997). Ĕ̈itimde program geliştirme. Ankara: Meteksan.

Eskicumalı, A. (2002). Eğitim, öğretim ve öğretmenlik mesleği Y. Özden (Ed). Öğretmenlik mesleğine giriş içinde (2- 30) Ankara: Pegem Akademi.

Eskicumalı, A. (2014). Eğitim ve sosyal değişme: Türkiye' nin değişim sürecinde eğitimin rolü, Sakarya Üniversitesi Ĕgitim Fakültesi Dergisi, (1).109-128.

Fidan, N. ve Erden, M. (1998). Eğitime giriş, İstanbul: Alkım Yayınları.

Gür, B. S. ve Çelik, Z. (2009). Türkiye'de millî eğitim sistemi: yapısal sorunlar ve öneriler. Ankara: Seta.

Hoşgörür, V. ve Taştan, N. (2012). Eğitimin işlevleri. Özcan Demirel ve Zeki Kaya (Ed.) Ĕ̆itim Bilimine Giriş içinde. (283-305). Ankara: Pegem Akademi Yayınc1lik. https://doi.org/10.14527/9786053186366.10

İçli, G. (2001). Eğitim, istihdam ve teknoloji. Pamukkale Üniversitesi Ĕ̆itim Fakültesi Dergisi, 9, 65-71.

Khan, F., Fauzee M.S. O. ve Daud, Y., (2014). A cursory review of the importance of teacher training: a case study of Pakistan. Middle-East Journal of Scientific Research, 21(6), 912-917.

Kalaycı, Ş., Albayrak, A. S., Eroğlu, A., Küçüksille, E., Ak, B., Karaltı, M. ve Antalyalı, Ö. L. (2005). SPSS uygulamalı çok değişkenli istatistik teknikleri, Ankara: Asil Yayın Dağıtım Ltd. Şti.

Karasar, N. (2005). Bilimsel araştırma yöntemleri. Ankara: Nobel Yayın Dağıtım.

Öztürk, N. (2005). İktisadi kalkınmada eğitimin rolü, Sosyo-Ekonomi Dergisi 1(1). 27-44.

Özyılmaz, Ö. (2013). Türk milli eğitim sisteminin sorunları ve çözüm arayışları, Ankara: Pegem Akademi.

Sayılan, F. (2006). Küresel Aktörler (DB ve GATS) ve Eğitimde Neoliberal Dönüşüm. Jeoloji Mühendisleri Odası. Haber Bülteni, 4, 44-51.

Sezer, S. (2018). Eğitimin toplumsal kurum ve süreçlerle ilişkisi, 05.11. 2019. tarihinde https://www.academia.edu/ alınmıştır.

Sipahi, B., Yurtkoru, S. ve Çinko, M. (2006). Sosyal bilimlerde SPSS'le veri analizi, İstanbul: Beta.

Sümer, N. (2000). Yapısal eşitlik modelleri: Temel kavramlar ve örnek uygulamalar. Türk Psikoloji Yazıları, 3(6), 49-74.

Snoek, M., Swennen, A. ve van der Klink, M. (2011). The quality of teacher educators in the European policy debate. Professional Development in Education, 37(5), 1-18. https:/ / doi.org/10.1080/19415257.2011.616095 
Şişman, M. (2008). Türk eğitim sistemi ve okul yönetimi. Ankara: Pegem Akademi. https:/ / doi.org/10.14527/9786050022087

Şişman, M. (2007). Eğitim bilimine giriş, Ankara: Pegem Akademi Yayıncılık.

Takala, T. (2010). Contributions of formal education to social development - What do we know on the basis of research evidence. Journal of Education and Research, 2, 1-8. https:/ / doi.org/10.3126/jer.v2i0.7616

Tezcan, M. (2016). Eğitim sosyolojisi, Ankara: Anı Yayıncılık.

Topses, M. D. (2016). Kurumlar Sosyolojisi, Ankara: Nobel Yayınevi.

Ünsal, S., Ağcam, R. ve Korkmaz, F. (2017). Exploring teaching profession from a sociological perspective: Evidence from Turkey. Universal Journal of Educational Research 5(5): 874-880.

Ünsal S. ve Korkmaz, F (2018). Eğitim ve sosyoloji ilişkisi. S. Ünsal ve A. Çetin (Ed.), Eğitim sosyoloji içinde (ss 35-58). Ankara: Nobel Yayınları.

Ünsal, S., Bağçeci, B., Meşe, N. N. ve Korkmaz, F. (2015). Eğitimin işlevlerini değerlendirme ölçeği: Geçerlik ve güvenirlik çalışması. Adıyaman Üniversitesi Eğitim Bilimleri Dergisi, 5(2), 245-265.

Yıldız, N. (2008). Neoliberal küreselleşme ve eğitim. DÜ Ziya Gökalp Eğitim Fakültesi Dergisi, 11, 13-32.

Yıldız, R. (2006). Eğitimin işlevleri, Erçetin, Ş. ve Tozlu, N. (Ed.) Eğitim bilimine giriş içinde (275-278). Ankara. Hegem Yayınları.

Yılmaz, K. ve Altınkurt, Y. (2011). Öğretmen adaylarının Türk eğitim sisteminin sorunlarına ilişkin görüşleri, Uluslararası İnsan Bilimleri Dergisi, 8(1), 942973.

Yılmaz, V. ve Çelik, E. H. (2009). Lisrel ile yapısal eşitlik modellemesi-ı, temel kavramlar. Ankara: Pegem Akademi.

\section{Summary}

\section{Introduction}

Teachers have great responsibilities in fulfilling the educational functions due to their acceptance as one of the main elements of the education system (Ada and Akan, 2007; Adıgüzel, 2008), being a significant factor affecting the social life and the quality of education (Çetin and Doğan, 2018; Snoek, Swennen and van der Klink 2011; 2011; Ünsal, Ağcam, and Korkmaz, 2017) and their roles in organizing the learning and teaching environment (Başarır, Sarı and Çetin, 2014). In this regard, this study analyzed teachers' perceptions and thoughts regarding the fulfillment of the educational functions. The advancement and development of countries, the healthy existence of the society, and the individual's self-fulfillment to live a happy life may be achieved through the fulfillment of the manifest and hidden functions that are expected from education. In this case, the issue to be discussed here is whether education fulfills its functions or not. Upon analyzing the relevant literature, there is no such a research specifically conducted on answering this question. This was considered as a shortcoming by the researchers. Accordingly, the problem statement of the research was "What is the fullfillment level of educational functions according to teachers' perceptions?".

In this regard, answers to the following questions were sought: 
1. What is the fullfillment level of individual functions of education according to teachers' perceptions?

2. What is the fullfillment level of social functions of education according to teachers' perceptions?

3. What is the fullfillment level of educational functions of education according to teachers' perceptions?

4. What is the fullfillment level of political functions of education according to teachers' perceptions?

5. Do teachers' perception levels in fulfilling the functions of education significantly differ across their gender, the type of school they work at, the grade they teach, the type of school they graduated?

\section{Method}

This study utilized a descriptive survey model, one of the quantitative research models, as it aimed to identify teachers' perception levels regarding the fulfilment of educational functions. The population of the research consisted of teachers working at schools affiliated to the Ministry of National Education in Kahramanmaraş city centre during the 2018-2019 academic year. The research sample held a total of 418 teachers working at primary, secondary and high schools in the central districts, Onikişubat and Dulkadiroğlu.

The study deployed "Teachers' Perceptions regarding the Fulfilment Level of the Educational Functions Scale", which was developed by the researchers. The statistical analysis revealed that the scale is a valid and reliable measurement tool that can be used to identify teachers' perceptions towards fulfilment level of the educational functions. The scale has four factors including individual function, political function, social function and economic function.

Parametric tests were used during data analysis since the assumptions of normality distribution and homogeneity of variances were ensured. In order to determine whether teachers' responses to scale items differed according to their gender, school type t-test was used; One-Way Analysis of Variance (ANOVA) was employed to confirm whether they varied depending on seniority, the grade they work and the school type they graduated, and LSD test was performed to determine the differences between groups.

\section{Results, Discussion and Pedagogical Implications}

This study analyzed the fulfillment levels of educational functions in line with the teachers' perceptions. The findings suggested that teachers' perceptions towards the fulfillment of social functions of education were at the neutral level. This result may be interpreted as the failure of education incompletely fulfilling its social functions. Educational institutions highlighted neoliberal concepts such as competitiveness and entrepreneurship by determining their programs and course contents according to the requirements of the business world, giving direction to the social functions of education, social justice and social solidarity, cultural values as well as equal opportunities (Saylan, 2006). This may have led teachers to develop negative perceptions towards the education's fullfillment of its social functions. 
The findings showed that teachers had the most positive perception towards the economic functions of education in terms of the item related to providing individuals with technological skills. The recent curriculum changes including digital and technological competence areas, the existence of robotic coding lessons and STEM applications may have affected teachers' perceptions.

In general, the fact that teacher perceptions towards the social, economic and political functions of education were at neutral level can be interpreted as the insufficiency of education system. The reasons for this situation can be listed as follows; ideological approach, lack of expertise, administrative problems, curriculum development problems, united classes, crowded classes, presence of central exams, problems with student personality services, inspection problems, problems related to teachers' organization and economic conditions, problems of teachers' quality, problems arising from bureaucratic structure, financing problems, mobile education problem, vocational and technical education problem, teacher employment problems (Özyılmaz, 2013; Yılmaz and Altınkurt, 2011).

Businesses and schools can cooperate to fulfill the economic functions of education. Qualitative and quantitative studies may be conducted regarding the effective factors on the teachers' perceptions towards the educational functions.

\section{Araştırmanın Etik Taahhüt Metni}

Yapılan bu çalışmada bilimsel, etik ve alıntı kurallarına uyulduğu; toplanan veriler üzerinde herhangi bir tahrifatın yapılmadığı, karşılaşılacak tüm etik ihlallerde "Cumhuriyet Uluslararası Eğitim Dergisi ve Editörünün” hiçbir sorumluluğunun olmadiğı, tüm sorumluluğun Sorumlu Yazara ait olduğu ve bu çalışmanin herhangi başka bir akademik yayın ortamına değerlendirme için gönderilmemiş olduğu sorumlu yazar tarafından taahhüt edilmiştir.

\section{Authors' Biodata/ Yazar Bilgileri}

Doç.Dr. Serkan ÜNSAL, Sütçü İmam Üniversitesi, Eğitim fakültesi eğitim bilimleri bölümünde öğretim üyesi olarak görev yapmaktadır.

Assoc. Prof. Dr. Serkan Ünsal works as an associate professor at Sütçü İmam University, Faculty of Education, Department of Educational Sciences

Abdullah GÖKDAŞ, Sütçü İmam Üniversitesi Rektörlük İdari Birimlerinde görev yapmaktadır. Eğitim bilimleri Yüksek Lisans mezunudur.

Abdullah Gökdaş works at the Rectorate Administrative Units of Sütçü İmam University. He is a graduate of Masters' at Educational Sciences 